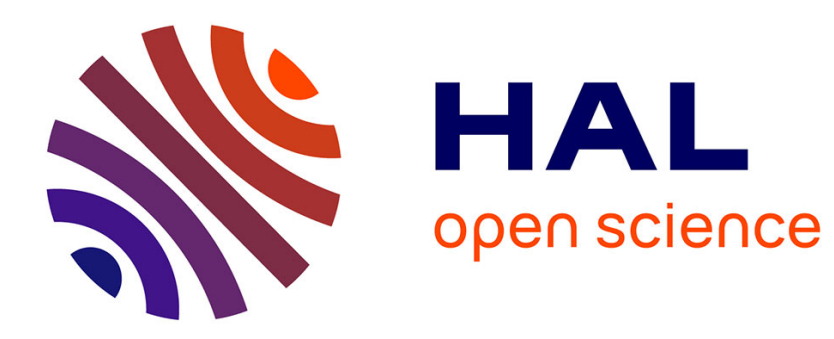

\title{
Negative interest rates in Switzerland: what have we learned? \\ Jean-Pierre Danthine
}

\section{To cite this version:}

Jean-Pierre Danthine. Negative interest rates in Switzerland: what have we learned?. 2017. halshs01571635

\section{HAL Id: halshs-01571635 \\ https://shs.hal.science/halshs-01571635}

Preprint submitted on 3 Aug 2017

HAL is a multi-disciplinary open access archive for the deposit and dissemination of scientific research documents, whether they are published or not. The documents may come from teaching and research institutions in France or abroad, or from public or private research centers.
L'archive ouverte pluridisciplinaire HAL, est destinée au dépôt et à la diffusion de documents scientifiques de niveau recherche, publiés ou non, émanant des établissements d'enseignement et de recherche français ou étrangers, des laboratoires publics ou privés. 


\title{
PARISSCHOOL OF ECONOMICS
}

WORKING PAPER Nº 2017 - 35

Negative interest rates in Switzerland: what have we learned

\author{
Jean-Pierre Danthine
}

JEL Codes: E52; E58

Keywords: negative interest rates; paper currency hoarding; safe haven currency

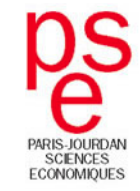




\title{
Negative interest rates in Switzerland: what have we learned?
}

\author{
Jean-Pierre Danthine \\ Paris School of Economics and CEPR
}

April, 2017

\begin{abstract}
The Swiss National Bank has introduced negative interest rates of minus 75bp in midJanuary 2015. Large exemptions on commercial bank holdings at the SNB result in the average rate being significantly less negative than the marginal rate. With this constellation the policy transmission to the real economy is asymmetric. It fully satisfies the needs of a SOE in search of a negative interest differential, not those of an economy aiming at a 'classical' monetary stimulus at the zero bound. While the Swiss design would make it possible to impose rates that are significantly more negative with modest complementary features, the unpopularity of negative rates makes it likely that the ambition to totally free monetary policy of the ZLB will be thwarted by democratic realities in the near future.
\end{abstract}

\section{Introduction}

In a small open economy (SOE) the interest rate plays a dual role. On the one hand, as always and everywhere, it represents the critical intertemporal trade-off, the key signal guiding saving and investment decisions. On the other hand, it is also the central lever through which the central bank can exerts its influence over the exchange rate. This dual role makes the Zero Lower Bound (ZLB) doubly constraining for a SOE. The ZLB may prevent 
the central bank from lowering the interest rate to the level appropriate to the situation of the domestic macroeconomy. Simultaneously it limits its capacity to react in the case of an excessively strong exchange rate. In both dimensions, it constrains the central bank in its ambition to offer monetary conditions appropriate to the economy.

In reality, however, most small open economies are less constrained than this description suggests because they enjoy (or suffer from) a positive risk premium, that is, their interest rates are higher than the rates prevailing on similar assets in the major advanced countries. So even when the major advanced countries find themselves at the ZLB, most SOE's still enjoy some remaining room for maneuver.

There are significant special cases, however. For a SOE with a safe haven currency such as Switzerland, the risk premium is in fact negative, and our starting observation thus takes full force. In recent times, Denmark also found itself in a similar situation, and one cannot exclude the possibility that, in specific cyclical phases, this description would apply as well for other well-run SOE's, such as Norway and Sweden for example.

\section{The ZLB challenge for a safe haven}

Figure 1 illustrates the Swiss negative risk premium that is the corollary of a safe haven currency. In the absence of a negative interest differential, the insurance against rare but severe crises offered by the Swiss franc would be provided freely, guaranteeing an unlimited demand ${ }^{1}$. Since the advent of the euro, and until the end of 2007 , the safe haven premium has taken the form of an interest rate difference of minus 1.7 percentage points on average, as measured by the difference between the rate on the 3-month Libor in CHF and in Euro.

\footnotetext{
${ }^{1}$.. thus leading to an overvalued currency with a severe overvaluation playing the same pricing role for the insurance benefit.
} 
Figure 1 also displays the collapse of this interest differential with the crisis-induced convergence of monetary policies starting in the Fall of 2008. The differential even turned positive, if only briefly, in the course of 2014, when the European Central Bank (ECB) introduced a negative rate slightly ahead of its introduction by the Swiss National Bank (SNB). The introduction of a minus 75 basis points (bp) interest rate on commercial banks deposits at the SNB in January 2015 reinstated a (modestly) negative differential.

That the crisis, and with it the disappearance of the traditional interest differential coinciding with a renewed appetite for the safe haven, constituted a significant policy challenge is clearly displayed in Figure 2. Figure 2 tallies the real effective exchange rate (REER) of the franc computed with respect to the 27 major trade partners of the Swiss economy since 1990. It shows that the start of the crisis coincided with a sharp real appreciation of the CHF, from a somewhat undervalued level in mid-2007 and reaching historic proportions illustrated by the dot at level 138 . This is the estimated value the index reached on the $9^{\text {th }}$ of August 2011. The real appreciation against the represented currency basket amounted to about $50 \%$ over a period of 4 years, representing an unprecedented challenge for a SOE exporting more than $50 \%$ of its production.

After the massive quantitative easing operations effected in August 2011 showed only some fleeting success in taming the rise of the franc, the Swiss National Bank decided on September 6, 2011 to impose an exchange rate floor at the rate of $1.20 \mathrm{CHF}$ per euro. This extraordinary policy measure was justified by the extra-ordinary circumstances that prevailed at the time. It lasted a little over 40 months until the $15^{\text {th }}$ of January 2015 . The abolition of the floor at that date can be viewed as a return to some form of normalcy. Indeed, the end of the floor was accompanied by the introduction of a negative interest rate on commercial banks' deposits at the SNB of minus $75 \mathrm{bp}$. This led to the 3-month Libor 
hovering around that level while the 3-month euro deposit rate was close to zero. In other words, the Jan 15 decision led to a re-introduction of a significant interest rate difference, although it remained substantially smaller than what had been historically typical. Acknowledging that the interest differential was insufficient, the SNB announced that the policy would be complemented with discretionary FX interventions. Indeed, substantial interventions proved to be necessary in the course of 2015 and again in $2016^{2}$.

The current policy package made of a curtailed interest differential compensated by FX interventions cannot, however, be viewed as a sustainable policy over the long haul. The SNB is already the central bank with the largest balance sheet in relation to GDP. One can hardly imagine that it will continue to grow at the same pace over the next 10 years. Hence the following legitimate question: what could be the next step in the eventuality that world interest rates remain abnormally low over many years, e.g., in the much-discussed scenario of secular stagnation?

\section{Negative rates 'Swiss made'}

To answer this question, it is useful to list some of the main properties of the negative rate policy as it has been introduced in Switzerland. The most spectacular element is the comparatively low rate imposed by the SNB on January 15 . No central bank had previously dared to push the rate this low. But another critical element is the large exemptions offered commercial banks before the negative rate applies. The exemption threshold is set at 20 times required reserves meaning that the average negative rate imposed on the deposits of commercial banks at the SNB is both much lower than the marginal rate, and less than 30

\footnotetext{
2 Totaling 86.1 billions CHF in 2015 and 67.1 billions CHF in 2016 according to the respective SNB Annual Reports.
} 
basis points in actuality ${ }^{3}$. An important related property is the fact that the ZLB continues to hold for retail depositors. Indeed, fearing the loss of what are, in normal times, very profitable client relationships and taking account of the unpopularity of negative rates (see later), commercial banks, in Switzerland as elsewhere, refrain from passing over the negative rates to retail depositors. And, despite the relatively deep negative rates, they can afford to do so thanks to the large exemption threshold set by the SNB. The corollary of this situation is that there is no risk of paper currency hoarding by the general public, a critical feature of the policy if further rate cuts were to be considered. Finally, it is equally important to observe that the marginal negative rate of minus $75 \mathrm{bp}$ has effectively guided financial markets, i.e., it is fully reflected in market rates throughout the yield curve. This is illustrated in Figure 3 where the interest rate on fixed income titles issued by the Swiss Confederation at various horizons are clearly seen to have been affected by the decision of January 15. Other market rates have been similarly influenced. On the other hand, bank lending rates have barely budged (Figure 4). This is a very significant observation for a bank dominated economy such as Switzerland as it suggests that very little macro-economic stimulus is to be expected from a negative interest policy so designed. We shall return to this point later. Even more striking, but possibly specific to the Swiss banking constellation, Figure 5 shows that a set of important mortgage rates have rather shown a tendency to increase (after some hesitation) subsequent to the initiation of negative rates. This is particularly the case for the all-important 10-year fixed rate mortgage. The accepted explanation is that the mortgage granting banks, notably all the domestically oriented commercial banks, confronted with their inability (or unwillingness) to benefit from the negative rates on their

\footnotetext{
${ }^{3}$ Although this average is increasing with the increase in the SNB's balance sheet resulting from ongoing interventions. The exemption is CHF 10 mios for institutions not subject to reserve requirements
} 
funding side - the majority of their funding is represented by sight deposits - have commonly concluded that they should similarly resist adapting rates on the asset side of their balance sheet. They have even managed to increase their lending margins. This of course is not what one would expect in a highly competitive environment but it has to be seen in the context of an exuberant housing market that authorities have for years attempted to cool down with a variety of measures and constant calls for moderation. Such outside pressure can plausibly have formed the basis for the commercial banks' common strategy.

\section{What could be the next step?}

With this understanding of the key characteristics of the Swiss negative rate policy one is in position to reflect on what could be the avenues for restoring a more appropriate interest differential in a context of persistently low global rates. A more determined negative rate policy could build on the previously described features as follows. First, in order to go more deeply negative, the temptation to hoard paper currency at the wholesale level must be deterred. This can be achieved by levying a fee on cash withdrawals at the central bank. The fee would serve to guarantee that wholesale currency hoarding would be unprofitable. Its level would thus have to be adapted to the depth of the negative rates and possibly take account of the expected duration of the negative rate policy. To achieve the latter, the fee could be applied to cash deposits (rather than withdrawals) at the central banks and be made dependent on the length of time since the corresponding withdrawal. All in all, the fee structure must be designed to act as a sufficient deterrent and in practice it would never be levied. The second element of the policy consists of an increase in the exemption threshold, so that the burden on the banking system remains approximately unchanged despite the 
sharpening of the negative rate policy. One could gear the exemption threshold in order to maintain the average negative rate to its current level while lowering the marginal rate. This should enable commercial banks to persevere with their strategy of sparing the general public, that is, renouncing the passing of negative rates to retail depositors with the important consequence that paper currency hoarding by the public would remain unproblematic. If needed, this feature could be consolidated by a legal obligation, similar to the one in effect in Belgium, prohibiting banks from offering non-positive interest on their deposits.

With these modest additional features, a policy of deeply negative rates would be feasible that fully meets the needs of a SOE in search of an appropriate interest differential at the ZLB. As hinted at above, such a policy does not, however, satisfy the needs of an economy in search of a 'classical' monetary stimulus. This is the case at least for Europeantype bank centric economies where the failure of commercial banks to reflect the negative rates in their loan contracts implies an important missing transmission link of monetary policy. It is important therefore to examine alternative possibilities open to economies persistently confronted with the ZLB. This is what I do next.

\section{More radical options are democratically unfeasible}

There are two radical options, one more so than the other, to secure the possibility of lowering rates below zero without restrictions. The first one is obvious: it consists in eliminating paper currency altogether. The main proponent of this option today is Ken Rogoff (see Rogoff, 2014, 2016 but also Buiter, 2009, and Goodfriend, 2016) who argues that not only would the elimination of paper currency enable to 'unencumber' monetary policy from the constraint of the ZLB but also that it would have the additional benefit of rendering 
criminal activities dependent on paper currency payments more difficult. The other option is associated with the name of Miles Kimball (see Agarwall and Kimball 2015). Here the idea is to introduce a variable conversion rate between electronic and paper money and engineer a time path for this exchange rate that implies the same negative return on paper currency holdings as the rate imposed by the central bank on electronic money.

In my view, the Swiss experience with negative rates leads to the conclusion that neither of these options is democratically feasible today or is likely to be in the near future: negative nominal rates are so unpopular that a democratic majority in favor of any legal measure permitting the direct exposure of the person in the street to negative interest rates is unreachable. Today the public is not directly affected since negative rates have not been passed on to retail depositors. Yet, the population is very concerned because of their indirect involvement through their retirement accounts. This concern is propagated by the complaints of pension fund managers for whom reaching the (oft-state imposed) return objectives has been made significantly more difficult by the low rate environment. The SNB has been justified in observing that while low rates are indeed a major challenge for the pension fund industry and for savers in general, negative rates do apply only, and even then only partially, to the small fraction of investors' cash holdings, but to no avail. The negative rate policy of the SNB has been taken as a scapegoat and made responsible for all the problems created by the low rate environment. Be that as it may, if there is something predictable in the current very uncertain world it is that a popular vote for legal measures opening the way to either of the two radical options mentioned in this section and thus permitting to generalize and deepen the negative rate policy would be overwhelmingly defeated. The fact that in many countries the necessary legal changes need not be submitted to a popular vote should not be a source of comfort. It would be very unadvisable 
for a technocratic institution such as a central bank to adopt radical monetary policy measures in the face of such widespread popular disapproval. Doing so would generate significant risks to its independent status. Of course, the attitude towards negative rates is not set in stone and popular opinion can evolve. It is not clear, however, who the public relations officer for measures such as the abolition of cash or the introduction of an exchange rate formula between electronic and paper money could be.

\section{Conclusions}

The Swiss experience with negative rates contains two lessons that are worth keeping in mind for the world-at-large. The first one is that in the current configuration of modestly negative rates the transmission mechanism of a pure policy of negative rates is asymmetric. If the goal is to influence market rates, notably to restore a desired interest differential despite the constraint of the ZLB, as needed by an economy that is home to a safe haven currency, this goal can be achieved and the policy even strengthened (rates could be pushed significantly lower than the current minimum of minus 75bp) with reasonable efforts. But if the goal is to provide a 'classical' monetary stimulus at the zero bound, the ability to do so is very much in doubt. This is because the transmission through the banking system does not operate symmetrically above and below the zero level, at least for modestly negative rates.

The second lesson is that the ambition to totally free monetary policy of the ZLB is likely to be thwarted by democratic realities. This certainly would be the case in Switzerland where the resistance to negative rates in the general population makes it certain that the necessary legal changes would be defeated in popular votes. To move in this direction, serious and systematic efforts to explain the logic and the necessity of negative rates are 
indispensable. Whether such efforts have a chance of being successful in the near future is very much an open question.

\section{References}

Agarwal R. and M. Kimball, Breaking through the Zero Lower Bound, IMF Working Paper 15/224, 2015

Buiter W.H., Negative nominal rates : three ways to overcome the Zero-Lower-Bound, NBER Working Paper 15118, 2009

Goodfriend M., The case for unencumbering interest rate policy at the zero bound, paper presented at the Jackson Hole Economic Policy Symposium, August 2016

Rogoff K., Costs and benefits to phasing out paper currency, NBER Macroeconomics Annual Conference, mimeo 2014

Rogoff K., The Curse of Cash, Princeton University Press, 2016 
Figure 1: The CHF-euro interest differential

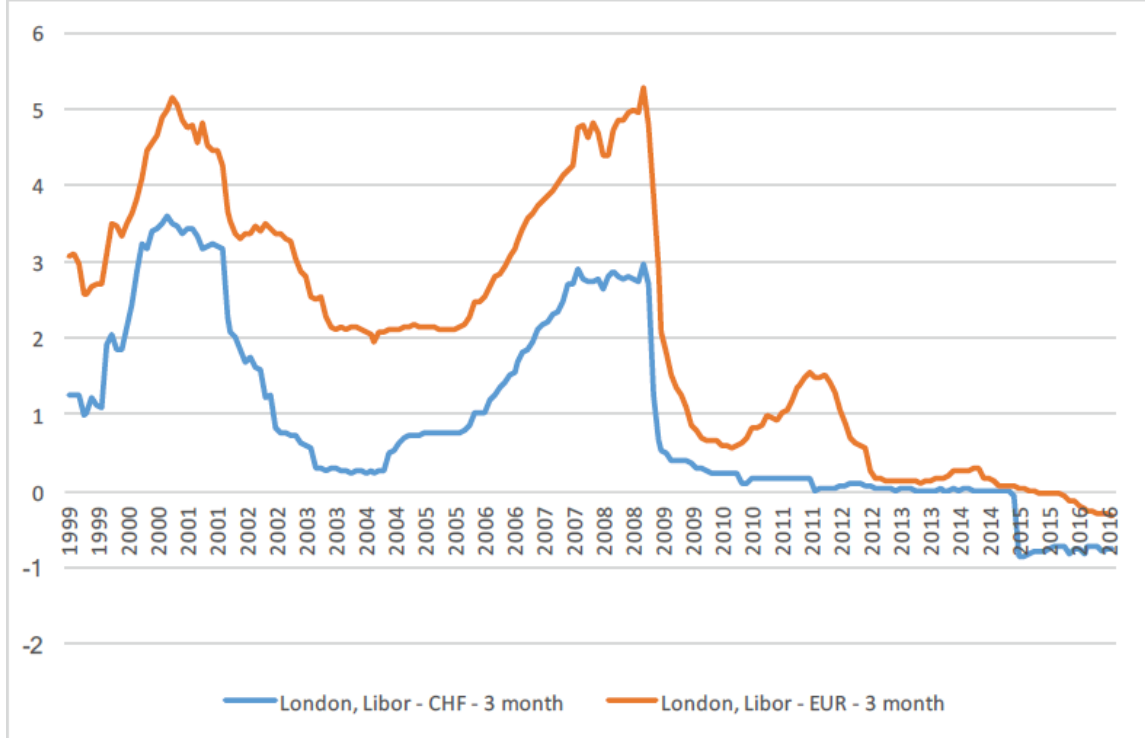

Figure 2: The Real Effective Exchange Rate of the CHF

\section{CHF effective exchange rate}

Trade weighted $27 \mathrm{CTY}$, real

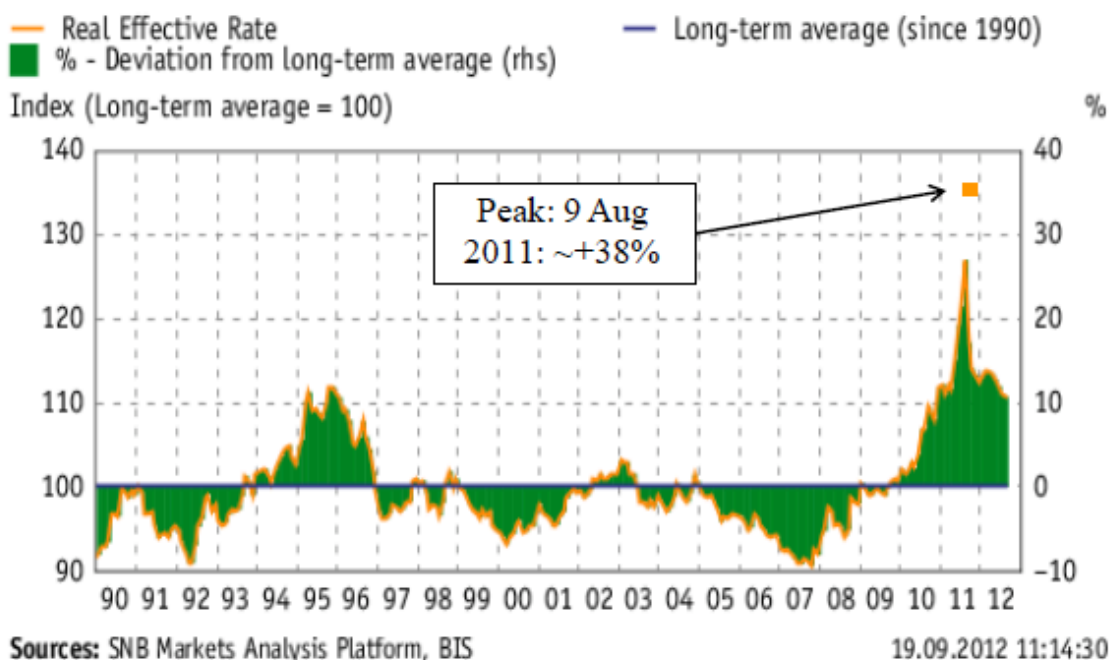


Figure 3: Swiss Confederation Bond Yields 2014-2016

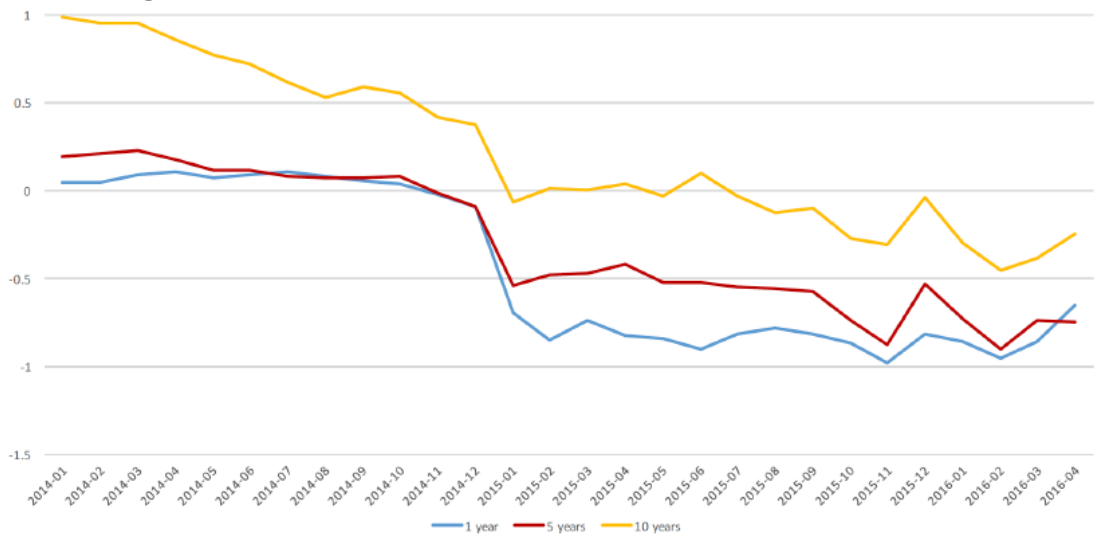

Figure 4: Bank Lending Rates - New Loan Agreements

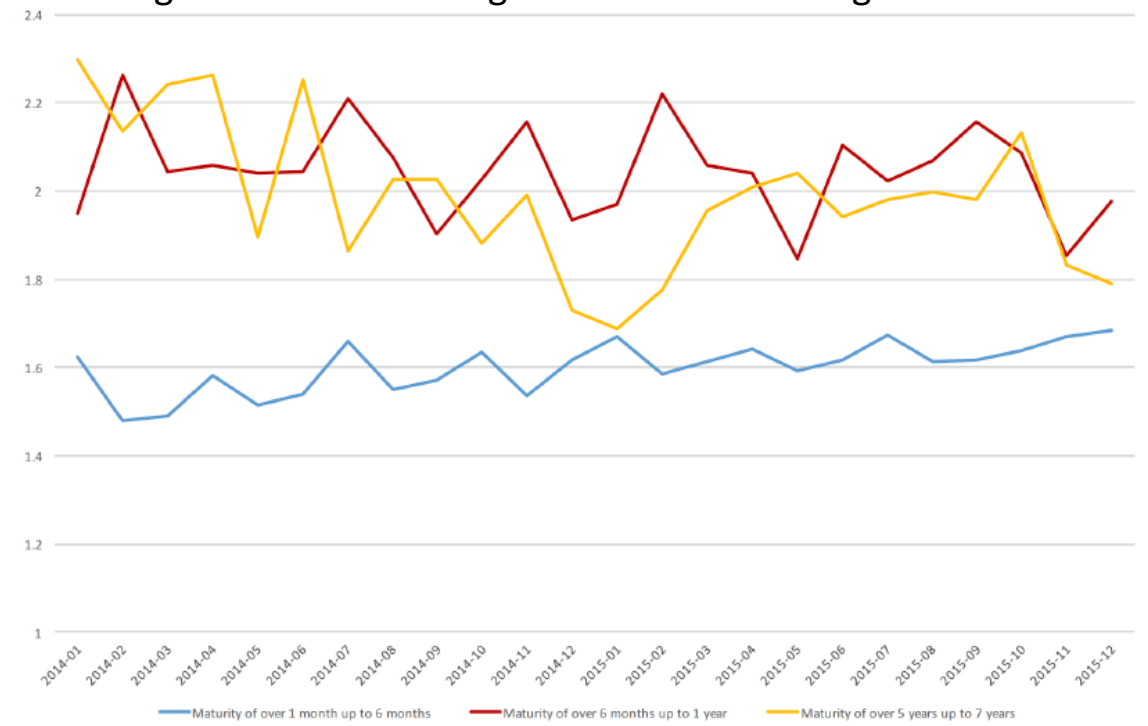

Figure 5: Mortgage rates at various maturity

Based on newly extended mortgages - Source SNB

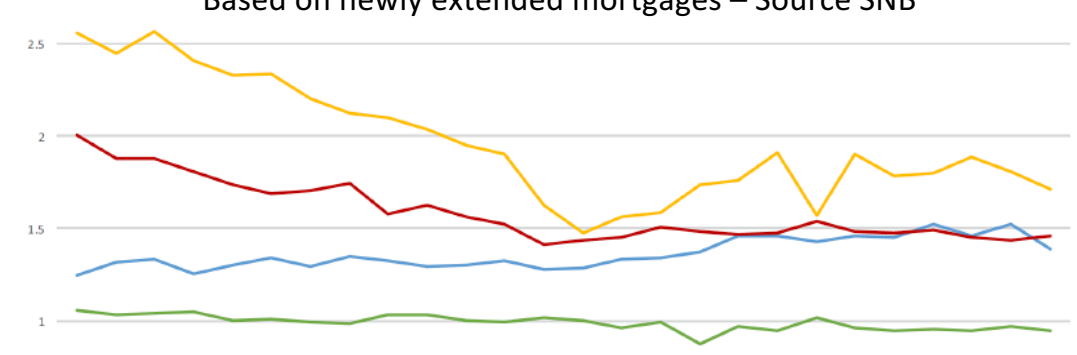

